\title{
ガラスのナノ・マイクロ加エにおける表面特性への加エ方法の影響 \\ Effect of micro/nano fabrication processes on glass surface characteristics
}

\author{
O古賀 洋介（慶大）正 佐藤 洋平（慶大）正 菱田 公一（慶大）正 三木 則尚（慶大）
}

\author{
Yosuke Koga, Keio University \\ Yohei Sato, Keio University \\ Koichi Hishida, Keio University \\ Norihisa Miki, Keio University
}

\begin{abstract}
Research of biochemical analysis system using micro/nano flow channel and fluid device has been ongoing actively. In micro/nano flow channel, effect of surface condition is larger than that of normal scale. Thus, physical or chemical characteristics such as surface roughness, zeta potential largely affect a system. In this paper, we used hydrofluoric acid to etch glass surface. We measured the relation between time and etching depth, and successfully indicated the relation between etching depth and surface roughness or zeta potential.
\end{abstract}

Key Words: Liquid Solid Interface, Surface Roughness, Etching, Zeta Potential

\section{1. 緒言}

近年、ナノ・マイクロ流路・流体素子を用いた生化学分析 システムの研究が盛んに行われている。ナノ・マイクロ流路 においては、従来のスケールと比較し表面の影響が大きくな る。そのため、表面粗さやゼ一夕電位など、表面の物理的、化 学的な特性が系に大きく影響する。このようなマイクロ流体 デバイスの材料としては主にガラスが使われている。フッ酸 を用いた化学ウェットエッチングが主な手法であったが、プ ラズマドライエッチングや、機械加工なども適応されてきて いる。ウェットエッチングの最たるものはフォトリソグラ フィである。フォトリソグラフィは、半導体デバイスや MEMS 分野などで現在最も利用されている微細加工技術で ある。この方法は、マスク作製、露光、現像プロセスによって レジスト上に微細なパターニングを行った後、ウェットエッ チングによって微細構造を形成するもので、大面積を一括で パターニングできることから、量産性に優れた加工方法であ るといえる。最小加工寸法は数百 $\mathrm{nm}$ と小さく、加工速度も高 いが、アスペクト比（穴径と深さ）は低く、三次元加工は不 可である。ウェットエッチングの特性である等方的エッチン グに対して、ドライエッチングは異方性をもつエッチング特 性を得やすい。プラズマドライエッチングの一つである反応 性イオンエッチングでは、試料に負電位を与え、エッチング ガスをプラズマ化し、試料上に引き込むことでエッチングを 行うものである。加工精度もアスペクト比も高いが、反応室 内の金属電極がエッチングされて污染や加工特性に影響を 与える可能性がある。文献[1]にあるように、機械加工は古典 的な加工方法ではあるが、多様な材料に対して極めて能率が 良い。三次元加工が可能など自由度の高い加工を行うことも できる。しかし、固体工具による力学的加工であるため、工作 物が小さくなると相対的に加工精度が低下寸る。よって最少 加工寸法としては数 $\mu \mathrm{m}$ 程度である。本研究では、ガラスを フッ酸によってエッチングした際の時間と深度の関係を実 験により求め、一定深さエッチングしたときの表面粗さと ゼー夕電位の関係を測定した。

\section{2. 原理}

文献[2]にあるように、ゼー夕電位とは、電気的に中性な領 域の電位をゼロと定義した時の、電気二重層に存在する扡散 層と固定相の境界であるすべり面での電位のことを云う。固 液界面に形成された電気二重層において、界面に沿った方向 に電界を印加すると、電気二重層内のイオンが移動し、巨視 的には溶液の移動が起こる。この流れを電気浸透流と呼ぶ。 ガラス表面のゼー夕電位測定では、ガラス表面の電位によっ て接する液体に生じる電気浸透流を利用して、HelmholtzSmoluchowski の式を用いガラス表面のゼ一タ電位を求めた。 デバイスの概略図をFig. 1 に示す。

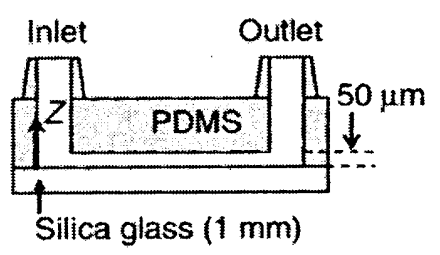

Fig. 1 Zeta potential measurement system

\section{3.フッ酸によるエッチング深度の検討}

本研究では、ガラスのエッチング状況に忘じた表面性状を 評価するため、時間に応じたフッ酸のエッチング深度を求め る必要がある。1.5\%に希釈したフッ酸を用いて実験的に求め た結果を Fig. 2 に示す。おおよそ比例関係になることがわ

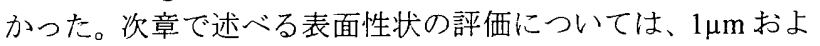
び $10 \mu \mathrm{m}$ の深度にエッチングしたガラスを用いた。

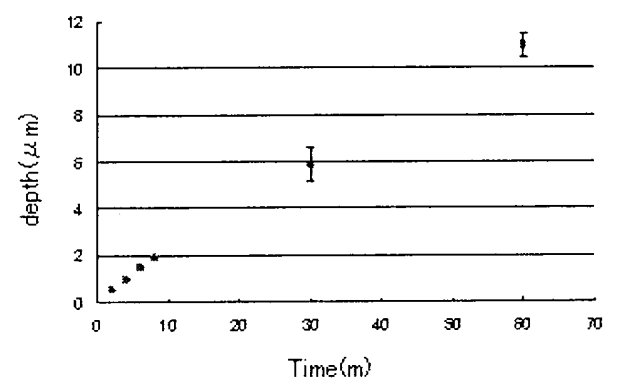

Fig. 2 Plot of time vs. depth 


\section{4. 表面粗さとゼータ電位測定}

ガラス表面に何も加工しない $0 \mu \mathrm{m} の$ 梁度のもの、1 深度で加工したもの、10 $\mu \mathrm{m}$ の深度で加工したものの三種類 についてそれぞれの表面粗さ（最大高さ Rz）およびゼー夕 電位を計測した。その結果を Fig. 3 およびFig. 4 に示す。表面 粗さ、ゼ一夕電位ともに増加していることがわかった。尚、2 章で述べたように、ゼ一タ電位は電気浸透流により評価して いる。すなわち、表面粗さの影響により、見かけ上ゼー夕電位 が変化したとも考えられる。この点は今後検討をする必要が あるが、電気浸透流の変化は確実に起こっているために、ナ ノサイズのチャネル設計において、考慮しなくてはならない。 プラズマエッチング、機械加工においても表面粗さの影響が あると考えられ、また特に機械加工においては残留応力の影 響も予測される。

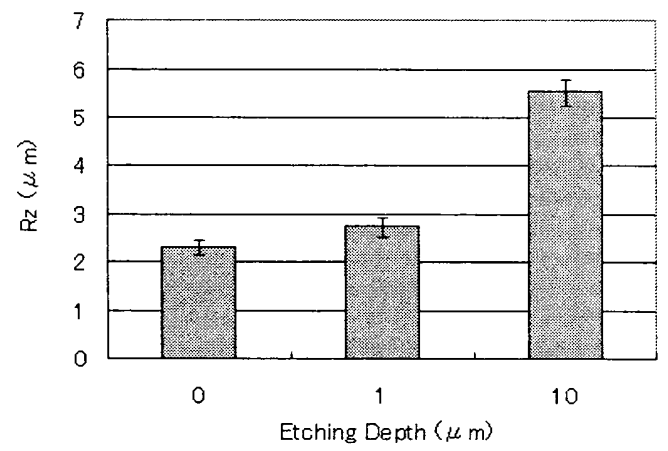

Fig. 3 Etching depth vs. Rz

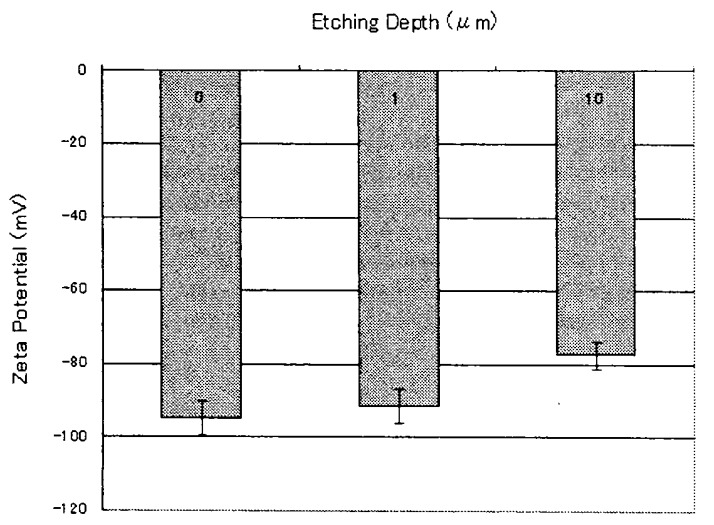

Fig. 4 Etching depth vs. zeta potential

\section{5. 結論}

フッ酸エッチングした時間増加に応じて、表面粗さおよび ゼータ電位はともに增加することが確認できた。今後の展望 としては、ドライエッチングであるプラズマエッチングや機 械加工で同様の実験を行い、表面性状の変化を評価する。評 価方法もゼータ電位の他に内部残留応力の計測も行う。

\section{謝辞}

本研究は、科学研究費補助金基盤研究 $(S)(21226006)$ の助成 を受けたものである。

\section{文献}

[1]超精密加工編集委員会, 千野俊猛, 日刊工業新聞社，「超精 密加工の基礎と実際」, 2006.

[2] Y. Kazoe, S. Miyakawa, N. Miki, and Y. Sato, "Fluorescence Imaging Technique of Surface Electrostatic Potential Using

Evanescent Wave Illumination." Applied Physics Letters, 95 (23) 234104. 2009 